\title{
Mob Lynching or Horde Lynching: A Threat to Rule of Law Along with Recent Supreme Court Guidelines
}

Upasana Borah"

5th Year Student, B.B.A LL.B (Hons), NEF Law College, Affiliated to Gauhati University, India

DOI: $10.36348 /$ sijlcj.2020.v03i08.001

| Received: 16.08.2020 | Accepted: 24.08.2020 | Published: 26.08.2020

*Corresponding author: Upasana Borah

\section{Abstract}

The Constitution of India is established upon the fundamental guideline of Rule of Law which in itself incorporates quality of Law. What's more, the Preamble to the Constitution depicts the thought where Justice, Freedom and Equality is to be made sure about to all the residents and Fraternity must be advanced among all the residents. However, it has been a long time since the Constitution was ordered and we have neglected to guarantee that they are being followed. The term 'We' incorporates the Legislature, Executive and Judiciary yet additionally the nation all in all. Crowd Violence is one of such territories where standards cherished in the Constitution are disregarded. In this article, the writers give a short review about the reasons related with crowd brutality, the current law in this regard and the location a significant issue of whether an explicit law is required. In this examination paper, I would concentrate on the current legitimate arrangements concerning savagery, the issues with these arrangements and requirement for extraordinary laws managing such viciousness with the assistance of doctrinal examination. I would likewise study the circumstance on different nations where such viciousness is pervasive and look at the techniques received by them to check such viciousness. I would likewise bring up the proposals made by the Supreme Court just as the bills presented by the Members of Parliament to check such viciousness.

Keywords: Indian Penal Code, Constitution of India, Code of Criminal Procedure, Supreme Court, Nagoun Court, Culpable Homicide, Preamble, Legislature, Judiciary, Executive, Violence.

Copyright @ 2020: This is an open-access article distributed under the terms of the Creative Commons Attribution license which permits unrestricted use, distribution, and reproduction in any medium for non-commercial use (NonCommercial, or CC-BY-NC) provided the original author and source are credited.

\section{INTRODUCTION}

Mob Lynching isn't new to the world. It has had its quality since quite a while. In any case, critical increment in such episodes in the previous not many years in India is both disturbing and the purpose behind carrying it into the spotlight. Horde Lynching is the term utilized for focused savagery by a gathering of individuals. When under the guise of controlling equity, a horde exacts savagery on an individual or a gathering without the plan of action to the legitimate framework, it is called Mob Lynching. No current enactment of India characterizes Mob Violence or Mob Lynching. Merriam Webster characterizes lynching as "to execute by horde activity without lawful endorsement or then again authorization". Lynching is utilized as type of discipline which is forced on the individuals by the individuals.

The vast majority of the occasion's blameless lives are influenced. Regardless of whether a specific individual or gathering are not guiltless, a fierce crowd can't go rogue and request execution. That is the point at which we accept, the significant element of the constitution, Rule of law, has been disregarded. It suggests that no individual can be rebuffed without power of law. This standard of rule of law alongside the authorization offices was intended to secure individuals and give equity. In any case, that hasn't been the case. The disorder is a direct opposite to the standard of law. One which is intended to secure us is being spurned.

The Indian Constitution reveres the standards of rule of law and the legal executive now and again has fortified its significance through different decisions. We need to guarantee that the position is reestablished once more. Furthermore, to do that another particular law in this regard is vital which can convey equity to all and to communicate something specific that nobody is exempt from the rules that everyone else follows.

\section{Need to investigate on the subject}

Of the 60 (revealed) assaults more than eight years, $58(96.7 \%)$ happened, as we stated, after Modi's administration came to control in 2014 and from that 
point forward the recurrence of these assaults has heightened pointedly and such demonstrations of individuals bringing law into their hands accepting to be right ethically and politically represents an extraordinary danger to the standard of law and individuals of minority bunches in the nation and steps must be taken to check and prevent such viciousness. The viciousness is brought about by vigilantes who have a few or the other political association with traditional gatherings and such individuals trust themselves to be politically right and safe while rebuffing anybody they accept to have submitted any offense. These exercises bring about advancing majoritarianism by spreading the convictions of the dominant part by smothering the privileges of the minority. The residents of a nation taking law into their hands is unsuitable and for a nation like India where residents are conceded key rights such lynchings are maltreatment of their entitlement to life, right to a reasonable preliminary and so on. For a nation that professes to be common it is imperative to guarantee that the minority bunches are not smothered to satisfy interests of the larger part.

\section{Examination questions}

Q1. What is current situation of laws identifying with horde lynching in India?

Q2. Who is answerable for such despise violations?

Q3. Why would that be a need to make a different offense identifying with horde lynchings in India? Q4. Which are different nations which face the comparative issues of horde viciousness?

\section{${ }^{1}$ ETYMOLOGY}

The inceptions of "lynch" are dark, yet it likely began amid the American Revolution. The verb originates from the expression "Lynch Law", a term for a punishment without trial. Two Americans amid this period are commonly credited for begetting the expression: Charles Lynch and William Lynch, who both lived in Virginia during the 1780s. Charles Lynch, has the better case, as he was known to have utilized the term in 1782, while William Lynch isn't known to have utilized the term until some other time. There is no proof that death was forced as a punishment by both of the two men. In 1782, Charles Lynch composed that his right hand had directed "Lynch's law" to Tories "for Dealing with Negroes."

\section{Supreme Court Judgement}

${ }^{2}$ The landmark judgement in Tehseen $\mathrm{S}$. Poonawalla v. Union of India \& Ors. put spotlight on Mob Violence. In that judgement, the Supreme Court emphasised on the importance of the command/ supremacy of law and the role of the State to ensure that people don't take law into their hands. The Supreme

\footnotetext{
${ }^{1}$ https://en.wikipedia.org/wiki/Lynching

2 Tehseen S. Poonawalla v. Union of India and Ors, (2018) 9 SCC 501 (India)
}

Court observed that "Lynching is an affront to the rule of law and to the exalted values of the Constitution itself'. It stated that such vigilantism, be it for whatever purpose or borne out of whatever cause has the effect of undermining the legal and formal institutions and altering the constitutional order. Lynching and mob violence are creeping threats that may gradually take the shape of a Typhonlike monster as evidenced in the wake of the rising wave of incidents of recurring patterns by frenzied mobs across the country instigated by intolerance and misinformed by circulation of fake news and false stories. The Court in its judgement laid down preventive, remedial and punitive measures to combat this social evil. Some of the major guidelines include:

1. The State Government shall designate a senior police officer as a Nodal Officer in each district for taking measures to prevent incidents of mob violence and lynching. A task force shall also be constituted so as to procure intelligence reports. The guidelines also detailed on the procedure, functions, etc., to be undertaken by the respective Police Station which reports such incidents.

2. It shall be the duty of every police officer to cause a mob to disperse, by exercising his power under Section 129 of CrPC, which, in his opinion, has a tendency to cause violence or wreak the havoc of lynching in the disguise of vigilantism or otherwise.

3. The Government shall take steps to identify the measures to stop such violence and lynching against any caste or community and to implement the constitutional goal of social justice and the Rule of Law.

4. The Government shall also take steps to curb the information which can incite mob violence. The police also shall cause to register an FIR under Section 153A of IPC and/or other provisions against any person who disseminates such messages.

5. The State Government shall prepare a victim compensation scheme under the provisions of Section 357A of CrPC within one month of the judgment and also to ensure that the family members of the victim are not further harassed.

6. It also detailed on the various procedures to be undertaken while trying the case of mob lynching by the Trial Court. Also, to set a stern example in cases of mob violence and lynching, upon conviction of the accused person(s), the trial court must ordinarily award maximum sentence as provided for various offences under the provisions of the IPC.

7. The States are directed to take disciplinary action against the concerned officials if it is found that such official(s) did not prevent the incident, despite having prior knowledge of it, or where the incident has already occurred, such official(s) did not promptly apprehend 
and institute criminal proceedings against the culprits.

The SC also recommended to the Parliament to create a separate offence for lynching and provide for adequate punishment for the same. It stated that a special law in this field would instill a sense of fear for law amongst the people who involve themselves in such kinds of activities.

\section{Explanations behind mob lynching}

There are two general classes under which the reason for horde lynching episodes occurring in our nation can be arranged. One is on the simple doubt that the individual or gathering of people have carried out or going to perpetrate a wrongdoing. Another ground is exclusively founded on the character of an individual. It can be because of religion, rank, sexual direction, dietary practices, political connection, and so forth. The occurrences which happen because of the reasons referenced in the last class are not simply horde savagery, yet they are loathing violations which target for the most part the minority networks and burdened individuals in the nation. They are likewise the purpose behind most events of such occurrences.

In any case, the genuine purpose for such wrongdoings is need for moment equity and narrow mindedness among the crowd. They are just marked as moment equity however it isn't real equity as they are directed against as it were assumed wrongdoers with no preliminary or methodology built up by law. They happen because of loss of confidence in the law. Also, the other explanation is bigotry. Detest violations are result of such narrow mindedness, ideological, strength and bias which at no expense be endured in case it will bring about a rule of dread. Human creatures are blinded by belief systems and dehumanized during the time spent lynching. Small time's opportunity of thought, activity, discourse, articulation, conviction, inner voice and individual decisions isn't being endured by the other and this is because of absence of target legitimization of acts and circumstances. Resilience must be cultivated and drilled and not permitted to be weakened in any way.

In the occasions when innovation is utilized for the advancement of the general public, it is abused into causing hurt to individuals. Web based life stages intended to interface individuals, are utilized as stage to take care of gossipy tidbits, bogus news and abhor messages. The greater part of the occasions, the viciousness like these are recorded and shared to make a feeling that equity has been finished. On the off chance that that isn't sufficient, at times government officials and chose agents as often as possible turn out with regards to the assailants, and accusing the casualties of the case of inciting the assault. The media additionally has become an ailment. There are news channels that have become the kangaroo courts with about six specialists and reckless commentators. They play the fault game more often than not.

Extremists and Bigots are going out of control in the nation. They consider themselves to be good vigilantes securing the consecrated request and apportioning equity. Strict conclusions and different belief systems have supplanted the rule of law and mankind. These abhor wrongdoings prosper above all in light of empowering atmosphere for detest discourse and viciousness which is cultivated and legitimized by different classes of individuals. There is quietness too from the authoritative get together. Law has assumed a lower priority. The authoritative hardware is either complicit or stupid onlookers to this new example of viciousness and meanwhile the crowds have acted as killers in different occurrences.

The spate of occurrences of lynching in the course of recent years has prompted an elevated feeling of instability among the underestimated networks. Lynching is conveyed for the sake of religion or due to the spread of bits of gossip. In this unique situation, the Supreme Court in 2018 portrayed lynching as an "awful demonstration of mobocracy" and set down rules for the Center and State governments to outline laws explicitly to manage the wrongdoing of lynching. In compatibility of this, the Manipur government came up first with its Law against lynching in 2018. The Manipur Law is in a state of harmony with the Supreme Court rules.

The Manipur Law characterized crowd lynchings as "any demonstration or arrangement of demonstrations of viciousness or helping, abetting such act/acts thereof, regardless of whether unconstrained or arranged, by a horde on the grounds of religion, race, rank, sex, spot of birth, language, dietary practices, sexual direction, political alliance, ethnicity or some other related grounds." The Law indicated that there would be nodal officials in each area to control such wrongdoings. The most generous and commendable commitment of the law is that it is the first in the nation managing the security and privileges of weak populaces which characterizes another wrongdoing of desolation of obligation of open authorities.

It expresses that Police officials who neglect to forestall the wrongdoing of lynching in their purview are at risk to be detained for a term that may stretch out from one to three years with a fine constraint of $\square 50,000$. Similarly pathbreaking is that it evacuates the insurance that is generally stretched out to open authorities accused of any offense submitted while acting in their release of authentic obligation. All despise wrongdoings can be punished under Section $153 \mathrm{~A}$ of the Indian Penal Code, identifying with encourage hostility between individuals based on religion, race, language, etc. Be that as it may, enlisting this wrongdoing requires earlier authorization of the State government, and most governments utilize this 
capacity to shield culprits of despise violations that are strategically and ideologically adjusted to the decision foundation. Under the Manipur law no earlier assent is required to enlist wrongdoings against open authorities who fall flat in their obligations to forestall abhor violations, for example, lynching. The Law obviously sets out the obligation and duty of the State government to make plans for the insurance of casualties and observers against any sort of terrorizing, intimidation, instigation, savagery or dangers of brutality.

It additionally recommends the obligation of State authorities to forestall an antagonistic situation against individuals of the network who has been lynched, which incorporates monetary and social blacklist.

The Law requires the state to figure a plan for alleviation camps and restoration in the event of removal of casualties, and passing remuneration.

This is noteworthy as a rule of lynching, it is discovered that States have just condemned the people in question, never bolstered the survivors who live not simply in misfortune and dread.

Propelled by this Rajasthan and West Bengal have detailed their form of laws to control crowd lynching. The West Bengal law is tougher as it accommodates discipline for lynching to death, is culpable with capital punishment or life detainment and a fine of up to $\square 5$ lakh.

Whenever copied by the Union and other State governments, such an authentic law could generously forestall loathe assaults, guarantee open authorities are devoted to their established obligations and casualties, and that their families and networks are guaranteed of assurance and equity.

There is no need to say more after discussing the above-mentioned observations and communications of the Supreme Court on the violence or mob lynching, and there is no other alternative except to implement the directions or guidelines given by the Supreme Court to control them.

\section{Do we truly require a specific law on mob lynching?}

Under the current enactment, the offense of Mob Lynching is being arraigned under the Indian Penal Code (IPC). The offense of homicide under Section 302, Culpable Homicide under Section 304, Attempt to Murder under Section 307, Hurt or Grievous Hurt under Section 323 or 325 alongside Common Goal under Section 34, Unlawful Assembly under Section 141 and 149, Rioting under Section 147 also, 148 and Criminal Conspiracy under Section 120 B and different arrangements are utilized for sentencing the blameworthy for Mob lynching or Mob Violence. As suggested by the Supreme Court in the Tehseen
Poonawalla case, the Police may likewise charge the blamed under Section 153A for IPC for dispersing unreliable and dangerous messages and recordings which actuated or prone to induce crowd viciousness and lynching of any sort or under Section 505 which gives discipline to the individuals who offer expressions 'making or advancing animosity, disdain or malevolence between classes'. Other than the arrangements of IPC, the arrangement of Section 223 of Criminal Procedure Code (CrPC) might be utilized for indicting the people blamed for an offense submitted throughout same exchange or individual blamed for an offense furthermore, people blamed for abetment of, or endeavor to submit such offense and so on might be charged and attempted in the court mutually And, whenever required, other important arrangements of some other law might be utilized for charging what's more, arraigning the denounced people. Be that as it may, the genuine inquiry which underlies these is whether these arrangements are sufficient or another law is required. In spite of the fact that the current arrangements in the corrective code are useful in rebuffing the culprits, it does not give some other insurance to the survivors of such episodes and it hasn't had the option to forestall such occurrences. Along these lines, it gets important to acquire another law which manages this. Some may likewise prescribe an alteration to the Indian Penal Code (IPC) to incorporate horde slaughtering or lynching as an offense. In any case, the creators' view is that a completely new enactment at the Central level is required to address this offense. This is a direct result of a few reasons. One of the significant reasons is that, the thought process behind such wrongdoings is to some degree curious. A portion of these are what is named as, Hate violations. These detest violations are not sufficiently managed under any of the present laws expect perhaps in the SC/ST Atrocities Act. Such detest wrongdoings are not to be endured. The State, in an assorted nation like our own, has the essential obligation to cultivate a mainstream, pluralistic and multi-culturalistic social request in order to permit free play of thoughts and convictions and conjunction of commonly conflicting viewpoints. Hence, to strengthen such qualities and to show that the any view or act opposite to it will not go on without serious consequences by the State and the Constitution, another law which explicitly manages such demonstrations of detest wrongdoing is required. Another explanation is that such cases must be optimized and should be observed cautiously by the Police and the lawful framework. In spite of the fact that this is relevant to all the offenses, in the instances of horde brutality, since the quantity of individuals engaged with the demonstration are enormous, quick activities are required. This is on the grounds that, there is a high possibility that the culprits vanish not long after carrying out the wrongdoing and evade the criminal arraignment. Another law can likewise detail on the strategy of examination, indictment and the preliminary to guarantee equity to the person in 
question. It will likewise help in distinguishing and rebuffing the carelessness and oversight of cops who neglected to play out their obligation in this regard. An arrangement can be made in the law identifying with the security of the observers in such cases likewise, to ensure their advantage. As gave in the Supreme Court judgment and in the state enactment identifying with crowd viciousness, another law can guarantee that alleviation and restoration is given to the person in question and their family. In this manner, another law will go far in guaranteeing that equity is guaranteed to the people in question and such occurrences may decrease because of the dread of arraignment and discipline.

- The instances of lynching and crowd brutality will be explicitly attempted by assigned courts in each region. Such courts will give cases a shot an everyday premise. The preliminary ought to ideally be closed inside a half year. "We may hurry to include that this bearing will apply to pending cases," CJI Misra, composing the judgment, said. Hindrance discipline

- The preliminary court should customarily grant the most extreme sentence under the arrangements of the IPC

- The courts may, on application by an observer or by the open examiner, accept such measures as it regards fit, for insurance and for disguising the character and address of the observer.

- The victim(s) or the closest relative of the perished will be given ideal notification of court procedures.

- The victim(s) or the closest relative of the perished will get free legitimate guide on the off chance that the individual in question so picks Correctional measures.

- Departmental move must be made against police or area authorities who neglect to act against the culprits. Such disappointment will be considered as a demonstration of conscious carelessness or potentially unfortunate behavior for which proper move must be made. The move will be made to its obvious end result ideally inside a half year.

The Supreme Court gave these rules in the long stretch of July, 2018 yet at the same time the quantity of vigilantism and crowd viciousness continued expanding because of which the Supreme Court were constrained to request that the Parliament enact another law. The Parliament has arranged a bill which is yet to be passed. It is known as 'The Protection from Lynching Act' however ordinarily alluded as 'Manav Suraksha Kanoon (MaSuKa).

\section{Perspectives on the draft}

The constitution of India ensures every individual the privilege to life and equivalent security of
Laws. The proposed draft means to guarantee the secured privileges of powerless people, to rebuff demonstrations of lynching, to set up unique courts and to reestablish the losses of such offenses. The draft of Protection from Lynching Act, 2017 gives express definition to the terms 'Lynching' 'Crowd' 'Casualty' and 'Hostile Material'. Lynching has not been characterized wherever in the Indian Penal Code anyway the demonstration of lynching incorporates a movement of trade which starting at now fall in the ambit of wrongdoing and along these lines examining Section 302, 326 and 141/149 makes lynching clearly an offense. The demonstration of Lynching doesn't finds its notice, basically, in the corrective code yet the trades that structure some bit of the demonstration are described as offenses, along these lines making the whole system guilty. A champion among the most basic thing is to fathom that what made this draft come up or on the other hand the demonstration of lynching coming into the picture is the inaccessibility of Rule of Law. It is the inaccessibility of execution of decides of law and that failure of state specialists of lawfulness. In case right move be made at the ideal time this situation would not have risen at the essential spot. The issue is the prerequisite of the law in light of the fact that the essential law requirement system of the state i.e police is being alluded to yet since this situation has risen, the current laws and framework are ill suited to prevent it and different lives are being lost due to lynching which we have to check it with some incredible law.

\section{${ }^{3}$ Impact of mob lynching in india}

1. State -

- It is against the values upheld in constitution of India.

- Every individual have certain fundamental rights any violence would be curtailment of this right.

- No regard to law and order in society.

- This may lead to growth of feeling of subnationalism.

- Radical and extremists organisations such as ISIS etc could take leverage of atmosphere created by such incidents.

\section{Society -}

- This impact solidarity of society and idea of Unity in diversity.

- This creates an atmosphere of majority v/s minority.

- It could aggravate caste, class and communal hatred.

- This may increase the extent of domestic conflict and subsequent militarization.

- Such acts shows loss of tolerance in the society and people are being swayed by emotions, prejudices etc.

\footnotetext{
${ }^{3}$ https://blog.forumias.com/mob-lynching/
} 


\section{Economy-}

- This impacts both foreign and domestic investment thereby adversely affecting sovereign ratings. Many International agencies warned India against mob lynching incidents.

- It directly hampers internal migration which in turn affects economy.

- Large resources deployed to tackle such menaces induces extra burden on stateexchequer.

- These incidents would lead to selective distribution of investment which may impact regional balance.

\section{${ }^{4}$ Recent cases of mob lynching in India}

\section{Khairlanji lynching, 2006}

In India, the first reported incident of lynching is Khairlanji lynching of 2006. In this lynching all members but one of a Dalit family was brutally mutilated, stripped, paraded in the village by the dominant Kunbi caste and the lone survivor had to fight for a decade get justice.

\section{Dimapur lynching, 2015}

A mob of about 7000-8000 people barged into the Dimapur Central Jail on 5th March 2015, dragged the victim out and beat him to death after stripping him. Victim was alleged to have committed sexual violence against a woman, and the news that the accused was a Bangladeshi Immigrant spread. With the aim of taking the revenge the mob lynched the victim.

\section{Jharkhand (chatra) lynching, 2016}

Jharkhand lynching refers to the lynching of two Muslim cattle traders in the Chatra District of Jharkhand by alleged cow-vigilantes. They were killed on the news that they were smuggling cattle but the real story was that they were having 8 oxens and were on the way to Chatra market to sell them. They were lynched and hanged by a tree.

\section{Alwar, rajasthan lynching, 2017}

A Dairy farmer named Pehlu Khan, 55 was beaten by a cow-protection vigilante mob over the alleged news of bovine-smuggling. Khan later succumbed to his injuries. Later all the Six identified accused were given clean-chit by the Police.

\section{Jharkhand lynching, 2017}

Seven people were lynched on the suspicion of being child-lifters. The violence arose after circulation on warning messages on WhatsApp that a gang of child lifter is active in the region. All the seven people were returning after some work related to Swachh Bharat Campaign. Four of them were Muslim whereas three were Hindus.

\section{Pratapgarh, rajasthan lynching, 2017}

On 17th June 2017, some municipal officers were trying to scare off women who were defecating in public by taking their photographs when an activist named Zafar khan intervened. He tried to convince them not to take photographs of defecating women, but in retaliation the officers punched and kicked him, and beat with sticks. Zafar succumbed to the injuries.

\section{Mohammed akhlaq's lynching}

The highly covered headline of lynching of Mohammed Akhlaq in September 28 in Dadri where a 50 year old was lynched over alleged consumption and storage of beef. The announcement was made from a nearby temple that he was consuming beef. On 30th September, Uttar Pradesh government ordered magisterial enquiry into the matter.

\section{Junaid khan's lynching}

The victim Junaid khan was pinched on a train. Junaid with his two brothers was returning from Delhi in a train after shopping for Eid. They had a conflict with some people over the seat but soon the actions turned into calling them "mullahs" and "anti-national", somebody was pulling their beard someone was playing with their cap. Then suddenly a packet in Junaid's pocket was termed as beef and now being termed as beef-eater Junaid and his brothers were in serious trouble, meanwhile some men pulled out knives and stabbed them. Junaid succumbed to the injuries.

\section{D.s.p. ayub pandith's lynching}

This incident of lynching was done by a mob outside Jama Masjid in Nowhatta, Srinagar. On June 22, a mob raising pro-al-qaeda and pro- Pakistani slogans lynched DSP Ayub outside Srinagar's Jama Masjid on the holiest night for Muslims during Ramzan, Shab-e-Qadr. The 57 year old DSP was deployed to keep an eye on the devotees who came for offering night-long prayers, which were led by Kashmiri Separatist Mirwaiz Umar Farooq, who was also the custodian of the Mosque. Around midnight a crowd started sloganeering for Pakistan and AlQaeda operative Zakir Musa. DSP Ayub who was in civil clothing, started making video of the people sloganeering. The mob on seeing this came to him with fists. DSP Ayub got his service revolver and shot 3 bullets below the waistline but was overpowered by the mob. The mob stripped him and hit him with sharp weapons and stones until death.

\section{${ }^{5}$ Dokmoka lynching victim's nilutpol das and abhijit nath}

1. All acts of violence carried out are nefarious, depraved and unacceptable. Mob lynching is a debased act of barbarism and in recent times Assam has seen an increasing number of heinous

\footnotetext{
${ }^{5}$ https://www.pratidintime.com/mob-violence-rise-in-
} lynching-justice-delayed-for-victims/ 
mob violence that seems to be turning into a norm. While committing mob violence, the mob doesn't identify with the creed, caste, gender or race neither can the causes of one incident of lynching can be compared with the other. Circumstances that lead a mob to commit an act of violence are several, however, one aspect remains the same, the persons who have been lynched, their lives along with that of their families will never be the same. A mob lynching incident that shook Assam in 2018, was the brutal lynching of Abhijit Nath and Nilotpal Das (Abhi-Nil). Today marks the two-year death anniversary of Abhi-Nil. On this unfortunate day, the boys were travelling to Dokmoka in Karbi Anglong district and through rumours on WhatsApp they were suspected as child kidnappers (Xopa Dhora). This age-old myth and ignorance of the locals claimed their lives. They were pelted with stones, beaten and videos were shot where both of them begged for their lives. However, two years later Abhi-Neel awaits justice. Such delays are a disappointment for not just the families of the victims but citizens across the country - the common man loses faith in the judicial system, governance and the law and order process. Gopal Chandra Das, father of Nilutpal Das, expresses his views on different factors that need serious introspection from different sections of the society. Das commented, "A fast track trial was supposed to be carried out, so we thought justice too will be served at the earliest. However, that didn't seem to be the case." Das explained initially there was an uproar across the state for seeking immediate justice as there was sufficient evidence to prove it. Also, social organisations, activists and the people of Assam came forward to support them. This proved in favour of the victims as the court proceeding went smoothly. However, after a few months the entire proceedings started to become irregular and the public memory also seemed to fade away. When the lynching case of Abhijeet Nath and Nilotpal Das had gone to trial, it seemed like an open-and-shut case. There were many witnesses; the case was expected to be in favour of the victims. But, the trial is still trundling. "A turning point that made the case weak was when witnesses turned hostile," Das added. Das tells, "There are around two witnesses who are willing to speak but much can't be expected of them as well." Initially, the witnesses had appeared at Diphu court and they spoke in favour of the victims but later changed their statements at the hearing in Nagaon court. Moreover, due to lockdown, nothing has proceeded further in the case. On June 9, there is a hearing on the objection of bail for the accused but it is uncertain a hearing will happen. So far the accused have pleaded for bail thrice. Abhijit Nath's father Ajit Kumar Nath expressing his grief commented, "Justice delayed is justice denied and this is what has been served to both the boys and other victims as well. I am hopeful that the judiciary will be fair towards us. It has been a difficult journey. We appreciate everyone who has supported us so far but the fast track trial should move to a fast track court and witnesses turning hostile have been a setback in the development of the case. We believe the witnesses have been instigated to change their statements."

Both fathers believe that public support is essential. The public should appeal and request or even file a PIL to the concerned authorities to fast track all such cases to a fast track court. Das also believes proper education and awareness campaigns on superstitions and myths, especially in underdeveloped areas. Here the question arises are we really governed by the Rule of Law or we are violating the Rule of Law also How can some witnesses give fabricated statements in the court? The government and the police have a moral responsibility to deal with the mob lynching case firmly.

If the government does not take a firm step, it will be difficult to put an end to such incidents.

2. Last month despite a nationwide lockdown due to the spread of the deadly Corona Virus, Assam experienced two heinous mob lynching cases. On May 29, Sanatan Deka, a local vegetable vendor from Monahkuchi village near in Kamrup district's Hajo, about $35 \mathrm{~km}$ northwest of Guwahati was lynched to death by five persons for hitting their car with his bicycle. So far four accused has been arrested. In another shocking incident, Debashis Gogoi a 23-year-old youth from Nakachari Milgaon near Mariani town succumbed to injuries at Jorhat Medical College and Hospital on May 23. The victim was beaten to death while he was returning with a friend from a picnic spot. Witnesses at the crime scene stated the incident occurred after an accident happened on a road to a picnic spot through the Gabharu Parbat Tea Estate. Apparently, the incident escalated when both the victims hit two women plantation workers.

\section{Way forward}

Lynching has become a social danger all over India; along these lines the inside should accompany the law to manage it. The law should join the accompanying arrangements: It ought to be appropriate to all abhor wrongdoings, not simply lynching (for instance respect executing), paying little mind to the quantities of people who partake. Since the quintessence of what recognizes these sorts of wrongdoings isn't the quantities of assailants yet the inspiration of abhor behind the violations, in this manner, the law should arrangement managing singular detest violations. The law needs to recommend a substantially more extensive structure of required sexual orientation delicate reparation. The law should consolidate correctional activity against specialists who 
stand blamed for forsakenness of obligation, for the deferral in taking care of survivors of lynching. Under the pay plot for the people in question, the sum ought to be recuperated from the culprits of the wrongdoing. Each time there is an instance of respect killing, abhor violations, witch chasing or horde lynching we raise requests for uncommon enactment to manage these wrongdoings. Be that as it may, the truth of the matter is that these wrongdoings are only killings and the current arrangements under IPC and CrPC are adequate to manage such violations. Combined with the rules set down for Poonawala's situation, we are adequately furnished to manage crowd lynching. Be that as it may, what we need is expected requirement of the current laws and responsibility of the implementation offices. Crowd savagery is a disagreeable slur on our legitimate framework. It comes from the unreasonable idea of vigilantism and prompts political agitation. Such excrescence should be checked with an iron hand. Law is the mightiest sovereign in a cultivated society. The greatness of law can't be tarnished essentially in light of the fact that an individual or a gathering produce the disposition that they have been engaged by the standards set out in law to assume control over its requirement and steadily become law unto themselves and rebuff the violator on their own suspicion and in the way where they esteem fit (Krishnamoorthy v. Sivakumar and others (2015) 3 SCC 467). The standard of law must be maintained for any cultivated society to persevere.

\section{CONCLUSION}

All the cutting edge religions of the world portray the human life as valuable. The Universal Affirmation of Human Rights, which is the global gatekeeper for securing the human rights of individuals likewise recognize the significance of human life and expects to secure it. Life is valuable and the cutting edge state is compelled by a solemn obligation to secure the life of its kin. The Constitution of India puts a risk on the state to ensure the lives of the considerable number of individuals under Article 21 of the Constitution. Be that as it may, the ongoing expanding episodes of horde lynching and the Mob Violence is both a wrongdoing and a barbaric demonstration. It absolutely disregards the standards enveloped in the Introduction of our Constitution which is to make sure about to all the residents Justice and Liberty; and Fraternity among the individuals of the nation. We should comprehend that in our nation obliging pluralism is essential to make a strong and joined society. It can't at any expense become some portion of the ordinary undertakings. It is the obligation of the State to shield its residents from such vigilantes who attempt to shake the establishment whereupon the general public works. What's more, the best way to ensure is acquire an exceptional law that can both rebuff the culprits engaged with such exercises and secure the person in question and their family. The grandness of the law can't be soiled just on the grounds that an individual or a gathering produces the demeanor that they have been enabled by the standards set out in law to bring its requirement into their own hands and bit by bit become unto themselves and rebuff the violator all alone suspicion and in the way wherein they consider fit. Rule of Law must be maintained in all the social orders what's more, there is no special case to it.

\section{SUGGESTIONS}

At the individual level advances can be taken by the organization to guarantee fast equity, enrolling the FIR immediately, suppress of the cross-cases which add to encourage exploitation upon the effectively feeble and poor, subduing of bail applications by the blamed as they represent a genuine danger to the people in question and their family on account of the despise connected with the wrongdoing. Aside from this help and reasonable remuneration ought to be paid to the people in question or their family for the misfortune endured by them and they ought to be sans given legitimate guide to them to make sure about equity. The administration should find a way to pass the law requested by the common society, Manav Suraksha Kanoon (MaSuKa) which gives that the law to be made for crowd lynchings will be cognizable, non-bailable and non-compoundable and welcome a day to day existence detainment alongside a period bound preliminary, pay to the groups of casualties and the police activity to guarantee the assurance of witnesses. Much the same as SC/ST (Prevention from outrages) Act, 1989 what's more, the Protection of Women from Domestic Violence Act, 2005 are intended for making sure about equity and securing a gathering, MaSuKa would do likewise for the survivors of horde lynchings. The parliament ought to follow the rules gave however the Supreme Court to draft and pass another law to manage the instances of crowd lynchings which would give a limit of life detainment to the lynchers alongside to the authorities who legitimately or by implication partake in such brutality. The new law ought to likewise characterize the term "mob lynching". There should be strict laws that totally prohibit Mob Lynching and make it a punishable offence. Certain amendments are needed in our current laws where the word "mob lynching" should be directly indicated.

\section{REFERENCES}

1. https://timesofindia.indiatimes.com/india/moblynching-draft-new-legislation-to-stop-peopletaking-law-into-own-hands-says-sc-toparliament/articleshow/65019261.cms

2. https://www.hindustantimes.com/india-news/toend-mob-lynching-supreme-court-gives-an-11point-prescription/storypdknxkMYd3Caz3R27nSniP.html

3. https://indianexpress.com/article/opinion/columns/s upreme-court-on-mob-lynching-law-againstlynching-case-social-media-whatsapp-rumuors$5265173 /$ 
4. Indian Penal Code, 1860

5. Code Of Criminal Procedure, 1973

6. Constitution of India

7. Krishnamoorthy, Sivakumar, V., \& Ors, (2015) 3 SCC 467 (India).

8. Anti-Corruption Council of India Trust v. Ministry of Home Affairs \& Ors., Writ Petition (Crl.) No(s).191/2019 https://main.sci.gov.in/supremecourt/2019/24355/2 4355_2019_1_36_15467_Order_26-Jul-2019.pdf

9. The Manipur Protection from Mob Violence Ordinance, 2018 (Manipur Ordinance No. 3 of 2018).

10. The Rajasthan Protection from Lynching Bill, 2019.

11. The West Bengal (Prevention of Lynching) Act, 2019. 